Andreász Kosztopulosz - Éva Kuruczleki (eds.) (2020): The Challenges of Analyzing Social and Economic Processes in the 21st Century. University of Szeged Faculty of Economics and Business Administration, Szeged, https://doi.org/10.14232/casep21c.14

\title{
Socio-demographic trends and their macroeconomic context affecting the public sector
}

\author{
Tamás Szabó
}

\begin{abstract}
Demand concentrates space and vice versa with regard to the principle of rational public services: concentrated space broadens the needs in relation to task fulfilment and the possibilities of organizing public services. The theoretical question concerning the goodness of decentralised and centralised task fulfilment gets exciting when we compare the level of the provision of public services to social trends, and we examine the unintended functions of the applied practice and the latent impacts of these functions. Based on cross-sectional data, present study examines - with public education and health care focus - how access to public goods influences the social competitiveness of the resident population of each district in space. Furthermore, the study also addresses the direction in which the differentiated level of provision of each regions of the country exerts its migration and demographic impact.
\end{abstract}

Keywords: public services, education, health care, cluster analysis, thematic map, spatial categories, administrative level, competitiveness

\section{Introduction}

Numerous studies (Alekseeva-Nikonova-Yusupova 2014, Foucart-Wan 2018, Gómez-Knorringa 2016) show that consumers can be excluded from the consumption of private goods. Theoretically (!), the members of the society get equal share from the consumption of the public goods. Therefore, the scarcity or the abundance of public goods affects the population of an area to the same extent.

Regions within a nation state differentiate and attract newcomers in numerous ways, or on the contrary, they become a deserted area due to their position. The reason of the differentiation of each region, delimited also by administrative concepts may be for instance the low concentration of business associations (Szerb et al. 2019) or the lack of provision of public services (Szabó 2019). At the same time, the approach to competitiveness is decided on the basis of the competition for limited goods (Chikán-Czakó 2012, Lentner 2007). This statement also applies to public services. Territorial competition 'is a process between territorial units with the aim of enhancing the prosperity of the region's or the town's population through the promotion of the development of regional and local economy. Certain groups try to influence that development explicitly or often implicitly via local policies while competing with other regions' (Lengyel 2016).

Competitiveness therefore can be measured in territorial relation as well, thus the competitive position of areas within the same nation state can also be measured and compared to each other. As a consequence, Lengyel's definition that 'territorial competitiveness can be considered as the competition of areas for resources' also 
applies to the accessibility of public services in the population retention relation of administrative units and territories within the nation states.

Based on the typing of resources (Lukovics 2008) it can be stated that the renewal of human resource is the engine of an area's ability to renew (Kónya 2015, Simonyi 2000). The fact that the population stays in place can be defined as the guarantee of the ability to renew. The provision of public goods is a necessary, but obviously an insufficient condition of staying in place.

Transport - including public services - is a complex system that not only integrates passengers and consumers, but it is a complex aggregation of synergistic elements built on one another and maintains the well-being of an area's resident population (Siska-Szabó 2015). Thus, public transport and the provision of mobility connects urban functions with rural functions in the different areas. But if permanent transport connection is not provided between these two types of functions within an area, the inhabitants of rural areas will receive less from the goods of certain groups of public services than their fellow citizens from the more mobilised area. Thus, the quality of their life - their well-being - deteriorates, moreover, they lag behind the population of that rural area (Campos Ferreira et al. 2017).

This process facilitates social erosion as well through the change in the given area's cohort structure. Rural areas which are cut off from urban areas by transport policy, become ageing areas (Samu 2019, Kollai 2019), because they lose access to services related to well-being. These services also facilitate the competitiveness of the given area and its population, therefore, the scarcity of these services foster the process of outmigration.

\section{Centre and periphery with regard to public services}

The greatest difficulty in defining the concept of public services is caused by the complexity of the concept. The concept of public service has played a significant role in several disciplines, so the concept can be explained from several aspects. (Hoffman 2013) As several Hungarian literatures point out (Hoffman, Horváth), the common feature of public services is that:

- it can be used equally by all members and groups of the community;

- their use is passive: so there is no need for agreement or active involvement of stakeholders;

- there is no competition between consumers in terms of access to the service.

As can be seen from the definition of public service, public involvement aims to eliminate the negative effects of market mechanisms and to create a kind of equilibrium in order to achieve these public goods.

From a fiscal perspective, economic centre and periphery can be defined on the basis of efficiency and profitability. Geographically, centres can be identified with the developed, while peripheries with the underdeveloped areas and municipalities. The core concept of this relationship system is the equality of values. There is an interdependency between centres of power (administrative centres) and peripheries; 
the power elite represents the centre, while the vulnerable mass represents the periphery. Geographically, the centre can be linked with administrative institutions (e.g. parliament, court). This may also mean that the better an area is provided with institutions, presumably the higher the concentration of the resident population is. In Hungary, as the consequence of the 2011 public administration reform, ${ }^{1}$ these centres are the district centres. Since the beginning of 2015 there have been 174 district centres. In Hungary, a district is a territorial public administration unit of a county comprising a certain group of municipalities. According to the 2013 data of the Hungarian Central Statistical Office, district centres can be reached on public road within 10 minutes, which can be considered a good level of provision from the viewpoint of the public administration. The access to public services however, are not that homogeneous: with special regard to education (Velkey 2019) or public health care (Tóth-Bán-Vitrai-Uzzoli 2018).

Figure 1 Number of general practices per district (2015)

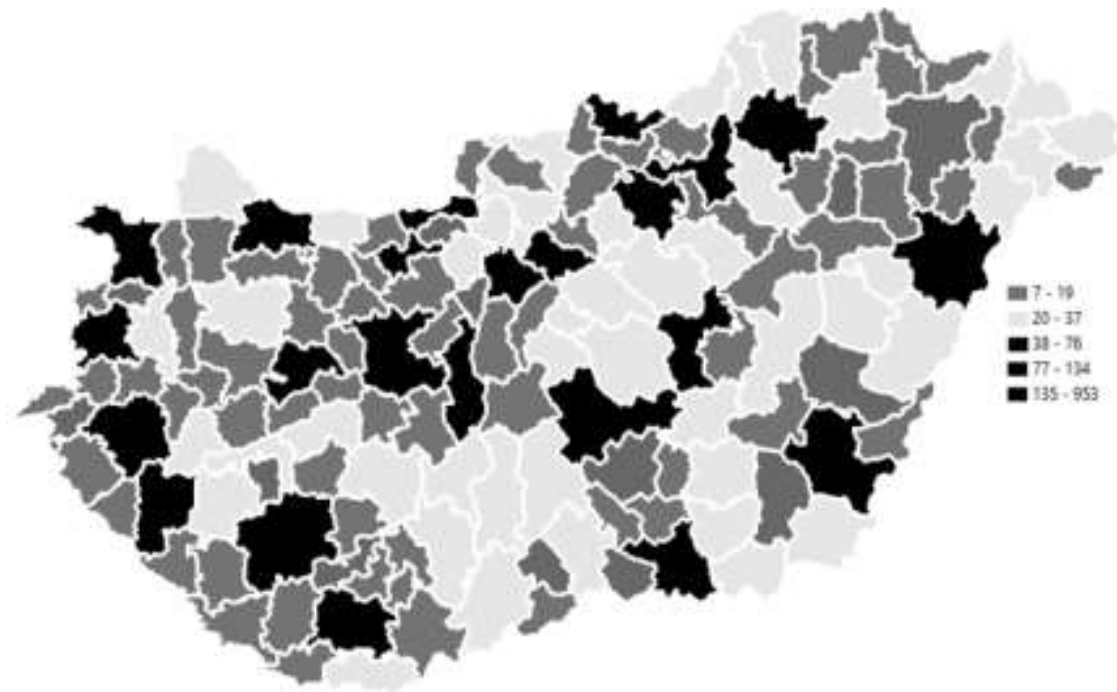

Source: own elaboration based on TEIR database

Performance of districts can be divided into several well-separable elements or dimensions (such as the status of technical infrastructure, the performance of the economy, the quality of human and social capital, the standard of living, the status of the environment) which are complex concepts on their own and they can be characterised by more kinds of indicators (Uzzoli 2015, Csath 2002, Pusztai 2009). In addition, the elements that make up each dimension are not always measurable or not

\footnotetext{
${ }^{1}$ The latest reform of the Hungarian public administration system was implemented in the framework of a programme which was named after Zoltán Magyary and was funded by the European Union. This programme covered all areas of public administration and induced a number of sub-programs in the spirit of efficiency and simpler, broader administration.
} 
available in appropriate quality. The latter - given that it is a legal act -provides mostly homogeneous quality in terms of administrative tasks, and as the map shows, it is evenly accessible.

The introduction of electronic administration ${ }^{2}$ further improves this picture. The situation is different however, with regard to the examined public services, as Figure 1 also reveals. In previous works, the definition of centres and peripheries was carried out with the simplest method possible: in general, border areas were considered to be the periphery, while areas close either to the geometric centre of the country, Pusztavacs, or - probably due to the relative proximity of the two points - to the capital city were considered to be the centre.

A Hungarian author's (Horváth 2007) article went into more detail on the theoretic and practical possibilities of definition, since the periphery by definition can be approached not only from the direction of the border, but also from the centre. By following the logic, the macroeconomic thesis can be reversed as well, according to which the demand concentrates space in public services (H1), however, the lack of public services defragments space and erodes the society. This hypothesis can be verified by the cohort structure, the level of qualification, the health condition and the change in the number of the permanent residents of the examined areas. The coherence among the concepts listed above provides opportunity to formulate a further subhypothesis, according to which $(\mathrm{H} 2)$ in areas where industrial output is higher, the level of outmigration is lower. A related sub-hypothesis $(\mathrm{H} 2 \mathrm{a})$ is that within the same county, the number of people with higher education degree is higher in regions with higher output than in areas with lower output.

During the examination of data related to public finances, Koós found that in the field of educational basic services (human public services), the optimal headcount required to the efficient and economical operation differs from each other. The author remarks at the same time, that besides optimal operation, other aspects such as fairness should also be taken into account. A study on the centralisation of public services (Kovács-Somlyódyné 2009) confirms this, by pointing out that the centralisation of potentials burdens not only peripheral areas but also central areas, since the former ones suffer disadvantage because the lack of access to public goods, while the latter ones feel the same as the consequence of the division of their resources. Therefore, when it comes to decentralisation, it should also be taken into account that the difference among the municipalities in the field of potentials - in present case in public education - may further distort the picture. Besides, the key for the permanent resident population to stay in place is the provision of human public services. In Hungary, areas comprising tiny villages are inadequately provided with human public services (Szörényiné 2005), which directly leads to the outmigration of the qualified and/or mobile layer from the municipalities of these areas (Obadovics-Bruder 2017).

\footnotetext{
${ }^{2}$ As part of the Digital Hungary programme, the 'electronic public administration framework concept' was introduced in Hungary, with the aim of digitalising a wide range of public administration services. With the adoption of resolution No. 1743/2014 (XII. 15.) on the tasks related to the extension of electronic public administration, the government made a decision on the implementation and on the cornerstones of the development of electronic public administration.
} 
Figure 2 The distribution of permanent resident population by qualification (2015)

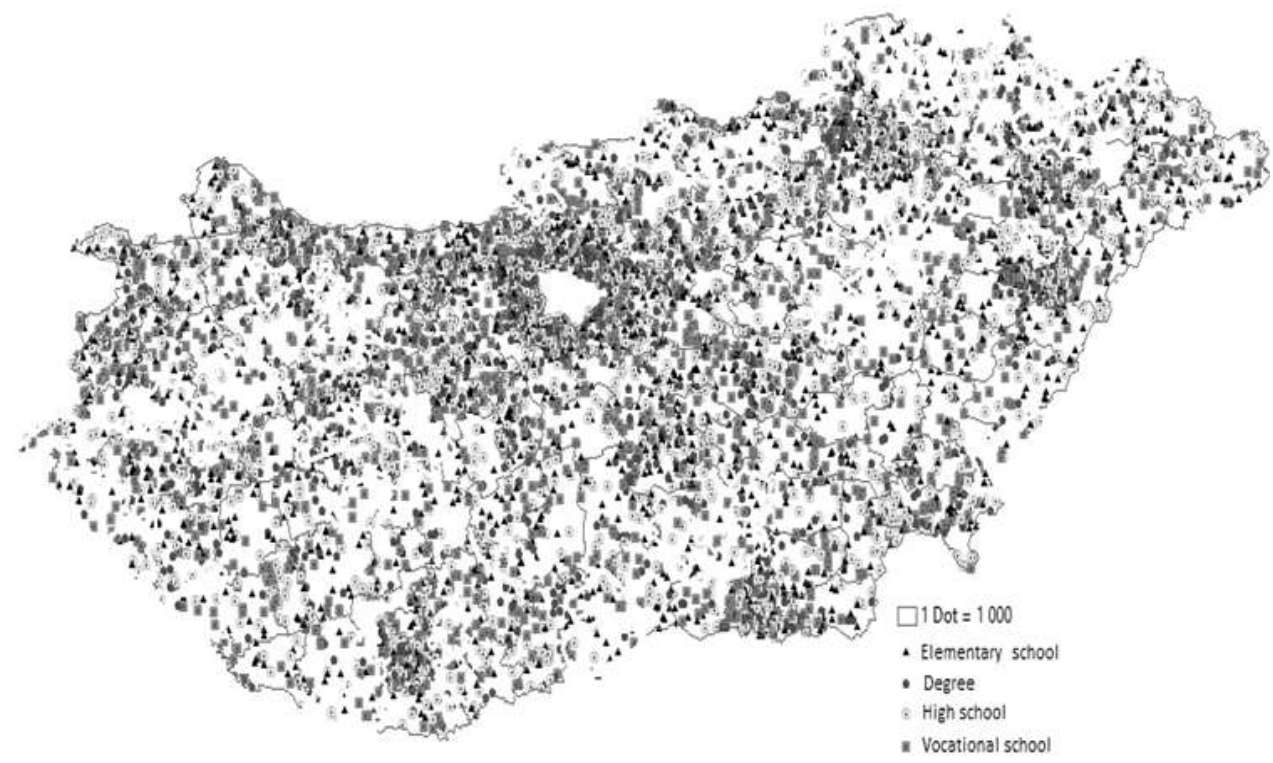

Source: own elaboration based on TEIR database

This process is also shown by figure 2, since within permanent resident population, people with secondary qualification or university degree are apparently concentrated in the agglomeration of the capital city or of other big cities. This is clearly the consequence of the pull effect of the labour market (Forray-Hives 2009).

One important driving force, cause and effect of territorial differences is the lack of human public services, which is one of the reasons and manifestations of inequalities, furthermore, it is also the basis and at the same time consequence of social, economic and power dependency, subordination, superiority, and imbalance (Nemes Nagy 1998). A research conducted with the involvement of the permanent resident population (Koltai 2016) reveals that when people decide whether to settle down in or move from a municipality, the second most important aspect that they consider after public safety is the accessibility of public services. Thus, it can be assumed, that (H3) in the examined counties, where output per capita is higher, the district-level GP and public education services are more intense.

With regard to public education services, in tiny villages the core problem is access, since public transport opportunities are rather limited - typically three or four bus rotations per day (Hungarian Central Statistical Office 2013) - therefore, it often takes the customer a whole day to arrange a few minutes of administration. The extent to which people are provided with cars has significantly increased compared to 1990 , but it is still hardly a solution for the inhabitants of ageing villages, or of villages that are turning into ghettos, since barely a third of the households possesses an automobile (Siska-Szabó 2015). In the first phase of the spatial rearrangement process of the elementary level public education - between 2004 and 2007 - in the course of the 
negotiations among local governments of different size and lobbying power, centres of micro areas and of local government associations were forced to act (Radó 2007). Associations for maintaining institutions have been set up for institutions that have actually been jointly maintained for decades, and the centres of local government associations have begun to fight to increase the number of students and to persuade the schools of the small municipalities that insisted on their independence, to join the associations. Mostly, when concluding the association agreements, the centres of local government associations made concessions to the associating municipalities in order to keep their institution and to further strengthen their role as centres of micro areas (Lányi 2008).

Figure 3 Municipal-level distribution of elementary schools located in the territories of local governments in 2015 (pcs) ${ }^{3}$

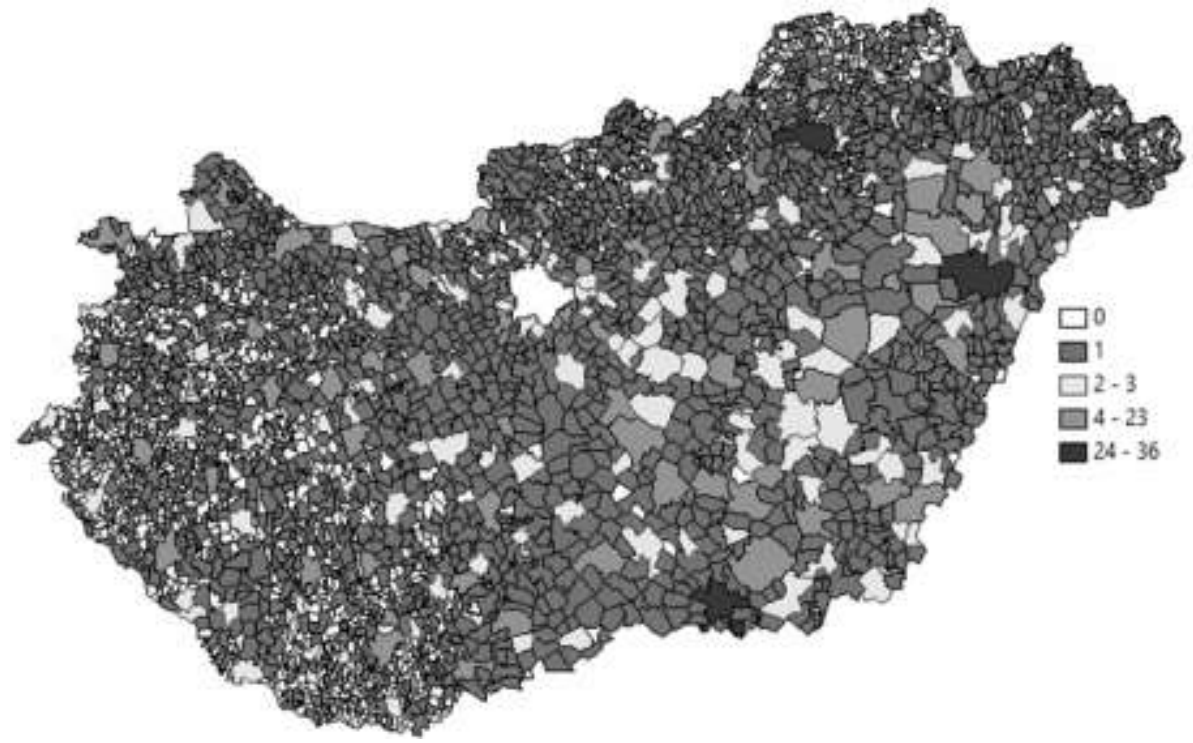

Source: own elaboration based on TEIR database

Finta (2013) pointed out in his analysis, that funds for the development of sub-areas comprising tiny villages are spent for the prompt resolution of acute social problems instead of real development. According to Finta, the main reason for that is the tendering system chosen by the associations, which may be the consequence of the outmigration of the intelligentsia from the mentioned sub-areas (Szabó-Kovács 2018, Obadovics-Bruder 2017) mainly to the capital city or to other Hungarian cities (Lux 2012), or to their agglomerations. The non-intended function of the reforms is the depopulation and ageing of the areas comprising tiny villages. As Figure 2 reveals, municipalities of these areas in Western Hungary, Southern Hungary and Northern

\footnotetext{
${ }^{3}$ Data of the capital city is not included
} 
Hungary were left without elementary school. Youngsters migrate from Western Hungary to regions close to the Austrian border. They also leave the regions comprising tiny villages of Northern Hungary and the ageing tiny villages of Southern Hungary (Obádovics 2018), to find good labour market opportunities, mainly in the agglomeration of bigger towns or cities. This process brings about a deterministic social phenomenon, according to which the number of active people decreases to a level within the given area, that the permanent residents are not able to compensate. As a consequence, the micro society erodes which suggests that (H4) where the number of recipients of social allowances is higher, the volume of industrial output is lower as well. This reasoning, in turn, justifies the examination of the territorial competitiveness of different public administration units within a nation state in the relevance of public services.

\section{Spatial analysis}

According to the results of research interpreted by the Hungarian authors (Nemes Nagy 1998, Lukovics 2008, Zám 2019), the difficulty in measuring territorial competitiveness lies not so much in its measurability, but rather in the unequivocalness of the quality of the chosen indicators.

In my analysis, I used the variables which were mentioned in the hypotheses formulated above. I included four counties ${ }^{4}$ in the empirical examination, and I examined these counties in pairs $(2<=>2)$ because the area, the permanent resident population and the population density of these counties approximates the most in the area conditions of Hungary. Thus, the emerging error value is the lowest in the mentioned dimensions (area and population). I use the volume of industrial output of the examined territory as independent (explanatory) variable, not GDP per capita. I used data reduction procedure as statistical method, which is a $K$-means clustering procedure. For this - considering the variables - I created a $z$-score value according to the following formula: $x_{i, l \sigma}=\frac{x_{i}-x_{s}}{\sigma_{x, s}} ;$ where $X_{i}$ indicates the standardised $z$-score value. During the operation, the average of the data series is subtracted from every observation data item and the remaining amount (difference) is divided by the standard deviation. The average of the data series which is equal with the resulting scale value will be zero, while its standard deviation will be one unit. As a result, the comparison of data series (variables) measured in different units and published accordingly, becomes possible according to uniform criteria. ${ }^{5}$ The aim of the grouping procedure often used in economic analyses is to group the observation units into homogeneous groups with the help of standardised variables.

\footnotetext{
${ }^{4}$ Komárom-Esztergom, Heves, Nógrád, Vas.

${ }^{5}$ It was necessary also because the outlier filtering revealed that while the normal distribution test of domestic migration was completed properly, the histogram image of industrial output did not draw a normal distribution curve. There were two outliers in the two examined counties, the towns of Esztergom (Komárom-Esztergom county) and Szombathely (Vas county). In these towns, the car factories (Opel and Suzuki) skewed the distribution curve with their added values.
} 
Elements recorded into the database are considered points of the space, where each point is represented by vectors. The values of these vectors are represented by variable values related to the given case. The resulting blocks comprising vectors can be classified into groups. The purpose of the procedure performed on a specific data series is to classify sub-areas of the counties into groups according to the volume of outmigration and industrial output. K-means cluster analysis has its own limitations. One of the most important limitations is that the unification of two clusters is irreversible, i.e. it cannot be modified afterwards. Furthermore, hierarchical cluster analysis is highly sensitive to noise and outliers, and it has difficulties in handling convex clusters and significant differences in size and it also tends to chop big clusters (Jánosa 2011). The latter problem in the present analysis does not occur, because I used the procedure on only one set of cross-sectional data. ${ }^{6}$ I summarised the municipality-level data of the migration balance sheet to the district level, and I proportioned the county-level data of the volume of industrial output based on the number of the permanent resident population of the districts Kukely 2008. Among public services, primary and secondary schools and medical service located in the territories of local governments are mentioned as basic indicators of social competitiveness. During the creation of data blocks, I set the following three categories in SPSS:

1. centripetal area, which is the cluster of 'attractive areas';

2. static area, which is the cluster of 'neutral areas';

3. centrifugal area, which is the cluster of 'ejector areas'.

The names of the clusters show the population retention ability, which - by comparing to economic output - may be a litmus paper in the context of social competitiveness.

The results of the statistical test which included 26 standardised sub-areas are shown in table 1 . After the classification of the values from 2015, the summarising table reveals that 20 sub-areas belong to the cluster of centrifugal areas. These are unstable areas in the context of the examined data. Compared to the proportion of examined areas, a low number of sub-areas (two altogether in two counties) can be qualified as socially and territorially competitive. Both of them are agglomeration centres, where car manufacturers pay the highest business tax to the towns. The table shows that two towns (Tatabánya and Salgótarján) ${ }^{7}$ which once had the same industrial structure ended up in different clusters. That is because after the system change, different companies settled down in the towns in different numbers, and because Tatabánya is located on a transit route, near the country's busiest motorway (M1) (Árva-Szabó 2014).

\footnotetext{
${ }^{6}$ Outmigration data and relevant industrial output data from 2015.

${ }^{7}$ See table 2
} 
Table 1 Spatial categories

\begin{tabular}{lccc}
\hline & centripetal & static & centrifugal \\
\hline Heves county & 0 & 2 & 7 \\
Vas county & 1 & 0 & 6 \\
Nógrád county & 0 & 0 & 4 \\
Komárom-Esztergom county & 1 & 2 & 3 \\
\hline
\end{tabular}

Source: own elaboration based on TEIR database

It is important to note that the 2018 data - of which a lot are not accessible regarding the data included in the examination - would presumably paint a different picture of the examined areas: in my own point of view, the proportion of the centripetal (1) and centrifugal (2) groups would be higher in the counties, which is the result of the current considerable, but territorially unbalanced economic expansion in the country (Lengyel-Varga 2019).

Table 2 The results of cluster analysis*

\begin{tabular}{|c|c|c|c|c|c|c|c|}
\hline \multicolumn{4}{|c|}{ 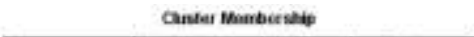 } & \multirow[b]{2}{*}{13} & \multirow[b]{2}{*}{$\mid \begin{array}{l}\text { Karmend } \\
\text { arrhe }\end{array}$} & \multirow[b]{2}{*}{3} & \multirow[b]{2}{*}{ insantar,s: } \\
\hline 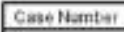 & dising & Clutin & Desanos & & & & \\
\hline 1 & Bsiassagal & 3 & 2247687220 & Is & 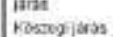 & 3 & $+24+2196,20$ \\
\hline 2 & 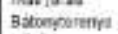 & & & 15 & Onusting & 2 & 13azesva: \\
\hline & ianas & 3 & 52.6911 .53 & & 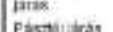 & & \\
\hline 3 & guxostrakal & 3 & 71810934.45 & $\begin{array}{l}18 \\
17\end{array}$ & 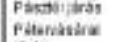 & 3 & 4623รอ98.25 \\
\hline 4 & Cetritmsisi & & & & intis & 3 & \\
\hline & garas & 3 & 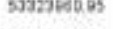 & 18 & 16osabejatis & 3 & 3121 \\
\hline 5 & Egrians & 2 & 200216241,0 & 19 & $\begin{array}{l}\text { Sabdeasai } \\
\text { jaits }\end{array}$ & 3 & $6501+32.675$ \\
\hline 6 & $\begin{array}{l}\text { Eectergenmi } \\
\text { sinas }\end{array}$ & 1 & 47482638,52 & 20 & Simeiniatas & 3 & 54617345,16 \\
\hline ? & Fuzusabsente & 3 & 29056470,20 & 21 & 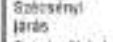 & 3 & s596433, \\
\hline 8 & Oyengosi & 3 & 13023045. 5 & 22 & $\begin{array}{l}\text { 8sompitsust } \\
\text { ijass }\end{array}$ & ${ }^{3}$ & 36785989.9? \\
\hline 9 & $\begin{array}{l}\text { Jaras } \\
\text { Hathoni iliras }\end{array}$ & 2 & 824) 12510 & 23 & 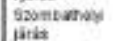 & 1 & 47<42836,53: \\
\hline 10 & Hovasejaràs & 3 & 50540245,08 & 24 & Traseina & $=$ & 7270ass?,45 \\
\hline 11 & Kabberijass & 3 & 25801600.83 & is & $\mid \begin{array}{l}\text { Bars } \\
\text { Trajeras }\end{array}$ & 3 & 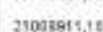 \\
\hline 12 & $\begin{array}{l}\text { nomarsmi } \\
\text { aras }\end{array}$ & 2 & 4496077057 & 3 & $\begin{array}{l}\text { vasnati inas } \\
\text { val }\end{array}$ & 3 & 55015524,40 \\
\hline
\end{tabular}

Source: own elaboration based on SPSS output *'járás' means district

A previous study found that the concentration of resident population leads to an increase in the extent to which the different areas of Hungary are provided with public services (Szabó 2019). But that concentration means different dynamics on each level of public administration. Inequalities show a different picture at NUTS 3 level than at district or at municipal level. Figures 2, 3 and 5; reveal how spatial potential (see the change in colour) influences the practice of using social allowances: 
Figure 4 Social allowances in cash provided by the state and allowances in kind provided by local governments in Hungary (2015)

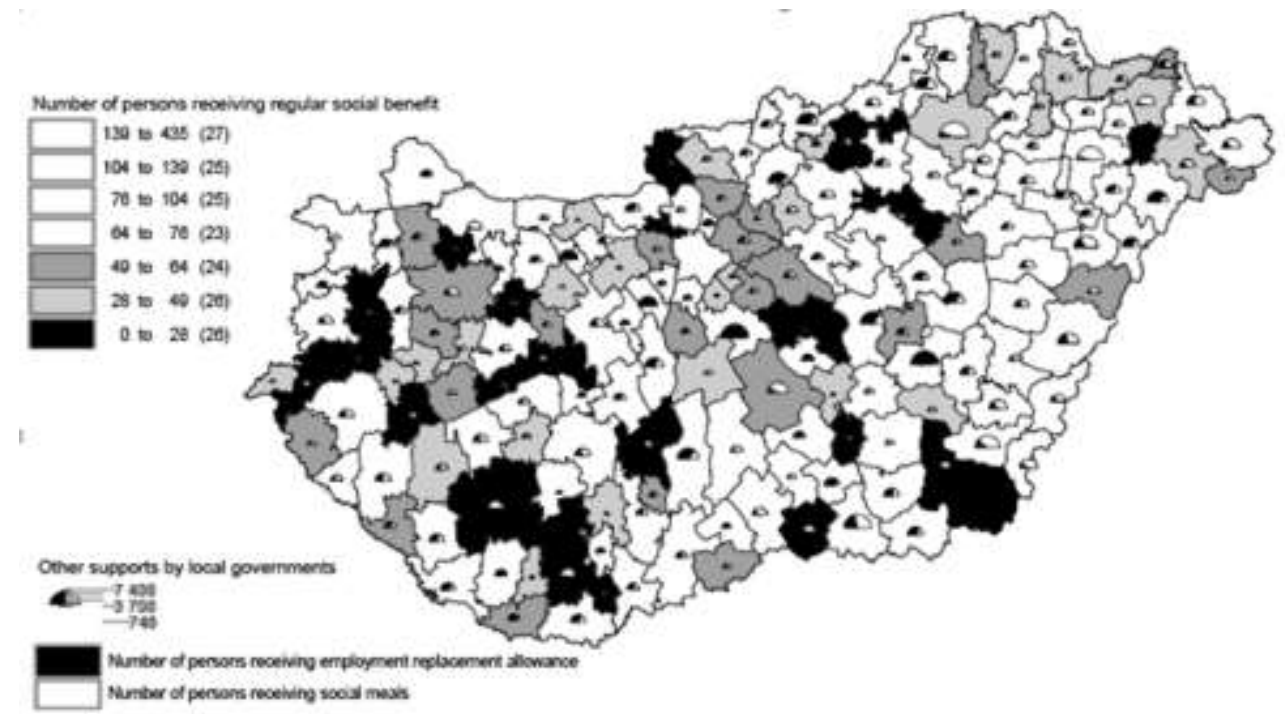

Source: own elaboration based on TEIR database

The recipients of social services are evenly distributed at the level of subareas: the data in the brackets in the legend are the numbers of sub-areas, classified according to the number of people who receive social allowance. On the other hand, however, with regard to allowances provided by local governments, it seems that where the government decree defined a higher level of general social allowances (see colour scale), it is more difficult there to find a job. Furthermore, the expenditure on the wage of public employees is also higher (considering that their number is higher) than the number of recipients of social catering, which is also regulated by local government decree. The map on the data presenting the volume of the industrial output of the examined areas (the districts of four counties) shows the intensity of the subareas of the counties:

In the context of industrial output (regarding the four examined counties), the hypothesis according to which higher industrial output results in a lower intensity of social provision (H4) cannot be confirmed. That is because the comparison of the two figures reveals that the number of recipients of social services in the affected areas is intensive (highly intensive in the sub-area of Hatvan, and moderately intensive in the sub-areas of Komárom and Tatabánya). Moreover, out of the sub-areas of counties, which were not subject to the examination, local governments of the sub-areas of Györ, Miskolc and Debrecen are also significantly affected by the constraint of providing social allowances. 
Figure 5 Industrial output per district and the level of qualification of the permanent resident population in the examined districts (2015)

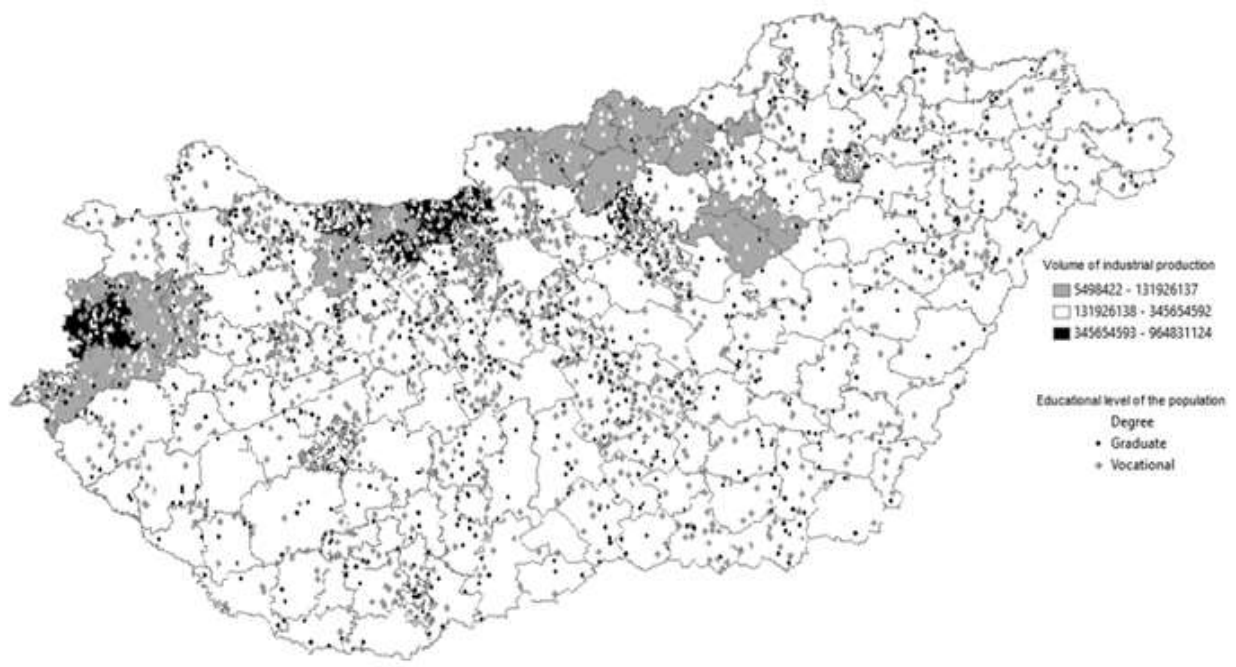

Source: own elaboration based on TEIR database

Figure 5 shows that sub-areas with higher industrial output concentrate employees with higher qualifications (sub-areas of Hatvan, Esztergom, Tatabánya, Komárom and Szombathely). Therefore, hypothesis H2a has been verified. Figure 6 presents outmigration at the level of municipalities:

Figure 6 The number of outmigrants within the permanent resident population (2015)

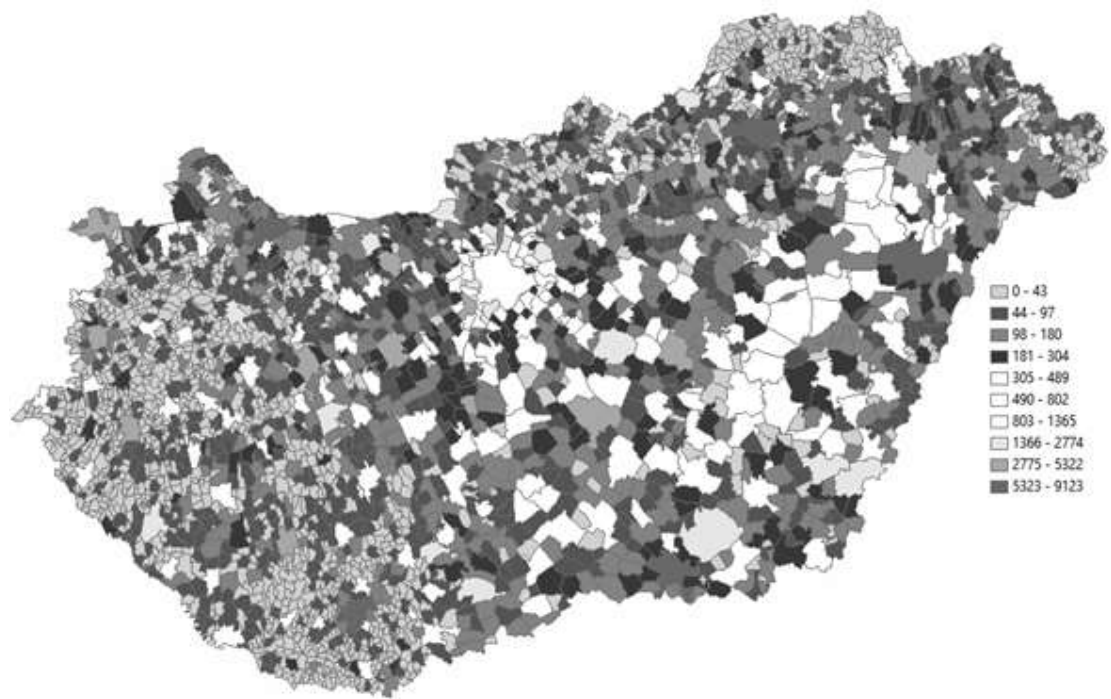

Source: own elaboration based on TEIR database 
Let us not forget that the volume of outmigration from areas comprising tiny villages - mainly in the villages of Western Transdanubia and Northern Hungary, where social reproduction level is low due to ageing (Obádovics 2018) - is high. At the same time, outmigration examined on the municipal level shows (figure 6) that in sub-areas with considerable industrial output, a high level of outmigration occurs in towns with the most added value (Hatvan, Tatabánya, Esztergom and Komárom as well). Therefore, hypothesis H2 saying that 'the level of outmigration is lower where industrial output is higher' has been disproved. An explanation for that may be the accession to the European Union in May 2004, through which the free movement of labour distorted the previously typical Hungarian labour market and social and family structures (Nagy-Fodor 2015, Bessenyei 2016).

In the developed districts, the concentration of the economy and of the resident population expands the provision of public services. On the contrary, districts full of tiny villages - after the dismantling of agriculture - not only witness a deterioration of their infrastructure and services, but also a decline in their reproduction level and economic competitiveness.

Qualified youngsters outmigrate from, or do not return to areas comprising tiny villages due to the lack of livelihood opportunities (figure 5). This selective mobility contributes to the distortion of the demographic and social structure of tiny villages, and at the same time - as Éva G. Fekete points that out-erects an important barrier to local developments (G. Fekete 1997). Experts, developers and mayors often consider tourism to be the key to the survival and even to the development of tiny villages.

In parallel, the intensity of education and medical care have drastically declined in these areas compared to the previous decades (Kiss 2016). That is partly justified in terms of sustainability, but while the deterioration of education can be explained with the low number of live births (Obádovics 2018), the decreasing number of GP services in areas comprising tiny villages is due to the lack of experts. The part of hypothesis H3 concerning GP services is based on opinions published by media outlets, stating that GPs seek to practice in prosperous places. In order to test the hypothesis, figure 3 should be compared to the map in Figure 1.

If we compare Figure 1 to Figure 3 which shows the intensity of provision illustrating primary schools in the territory of the municipality, it becomes clear that provision with respect to education concentrates around towns with high level of output. Nógrád is the only county among the examined counties, where one can find a municipality that does not have a primary school. At the same time, these local governments are all located close to towns of high output level. Therefore, the provision is available, but not locally. In order to surely verify this hypothesis, visual comparison is insufficient, the examination of the school-age resident population is required.

As for GPs, the characteristic of the volume of industrial output and of the number of GPs are the same. However, in the case of hypothesis H3 only the statement concerning medical provision can be accepted, since the number of primary schools and the proportion of industrial output are not comparable to each other because of their different public administration levels. Thus, this hypothesis has just partly been verified. Regarding the situation in Northern Hungarian areas, the result is partly 
latent considering that the number of areas comprising tiny villages is higher, thus, that the number of areas comprising tiny villages is higher, thus, the number of medical services per capita is lower, since the population density is lower, which at the same time confirms the statement formulated in hypothesis H3.

Hypothesis $\mathrm{H} 4$ partly referred to hypothesis H1, according to which 'the lack of public services defragments space and erodes the society'. The data presenting the intensity of the access to public services involved in the examination, have been visualised above.

The concept of social erosion means the ageing of the resident population and the loss of social reproductive capacity in the areas of the nation state. I examined the related hypothesis with the help of the following thematic map:

Figure 7 The number of people over the age of 60 in the permanent resident population (2015)

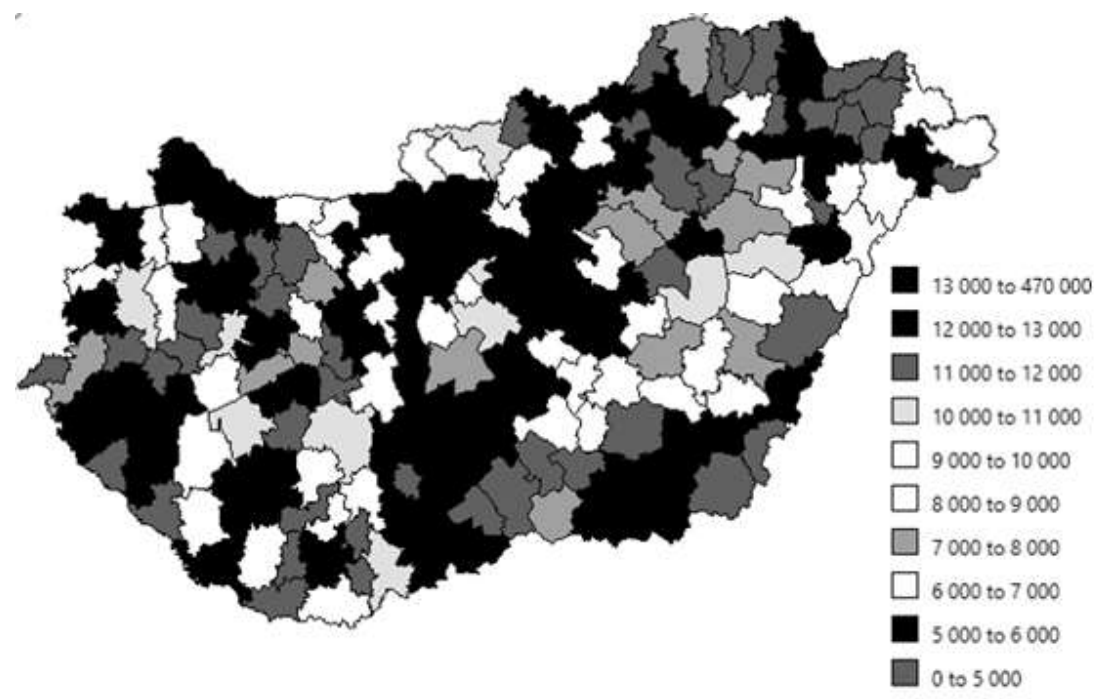

Source: own elaboration based on TEIR database

When examining the colour codes on the map, it becomes clear that the number of pensioners in the districts of the examined counties are high, even in districts with high industrial output like the Hatvan, Tatabánya, Komárom, and Esztergom districts. Namely in the areas, where people over the age of 60 are overrepresented - mostly areas comprising tiny villages in the examined counties -, the provision of public services is lower and outmigration is higher (figure 6), accompanied by high demand for social services and low number of live births (Obádovics 2018). If we take into consideration the areas comprising tiny villages around the sub-area of Hatvan, and the colour code of Szécsény district, plus the characteristics of all these in figures 3 and 6, then it will be easy to accept that this hypothesis (H1) is verifiable. 


\section{Conclusions}

As the summary of this study, I would like to raise attention to some emphatic conclusions. During the analyses it has been found that the concentration of the resident population leads to the enhancement of the provision of public services. At the same time this concentration means different dynamics at the different levels of public administration. Inequalities show a different picture at NUTS 3 level than it does at district or municipal level. When the analysis is made in the context of public services, the social characteristics and the economic output of the public administration levels below NUTS 3 in a nation state are not equivalent to NUTS 3 level aggregates. There are centripetal, static and centrifugal areas also below NUTS 3 level (municipal and district levels), because the lack of public services defragments the space and erodes the society. Employees with secondary or tertiary qualifications are concentrated in districts with higher industrial output. Thus, they often leave the areas comprising tiny villages, which, in the absence of the initiatives of the intelligentsia, become incapable of economic and social renewal.

\section{References}

Alekseeva, L. V. - Nikonova, T. V. -Yusupova, L. M. (2014): Institutional traps of human capital consumption: public goods production problems. Mediterranean Journal of Social Sciences, 5, 24, 131.

Árva, Zs. - Szabó, T. (2014): Közlekedéspolitika. Nemzeti Közszolgálati Egyetem, Budapest.

Bessenyei, L. (2016): A munkaerőpiac generációs struktúrájának alakulása a XXI. század első felében. In Tóth, A. - Gubik, A. S. (Szerk.): Magyarország 2025 ben és kitekintés 2050-re. Arisztotelész Kiadó, Budapest, 53-62.

Chikán, A. - Czakó, E. (2012): A vállalati versenyképesség szolgálatában. Magyar minöség, 21, 2, 11-14.

Campos Ferreira, M. - Costa, V. - Galvao D. - Cunha, F. (2017): Joao. Transport Research Procedia, 27, 125-132. doi:10.1016/j.trpro.2017.12.052

Csath, M. (2002): Erős társadalmi tőke, sikeres nemzet. Valóság, 45, 5, 82-92.

Finta, I. (2013): Az aprófalvak fejlesztési igényei és a nemzeti szintű fejlesztési tervekáltal nyújtott lehetőségek. In Kovács, K. - Váradi, M. M (szerk.) Hátrányban vidéken. Argumentum Kiadó, Budapest, 315-330. (ISBN:978963-446-682-6)

Forray R., K. - Híves, T. (2009): Az iskolázottság, a foglalkoztatottság és az ingázás területi összefüggései. Szociológiai szemle, 42-59.

Foucart, R. - Wan, C. (2018): Strategic decentralization and the provision of global public goods. Journal of Environmental Economics and Management, 92, 537558.

G. Fekete, É. (1997): A kistérségi tervezés néhány sajátossága. Tér és Társadalom, $11,3,101-105$.

Gómez, G. M. - Knorringa, P. (Eds.). (2016): Local governance, economic development and institutions. Springer. 
Hungarian Central Statistical Office (2013): A közúti közlekedés területi jellemzöi. Központi Statisztikai Hivatal, Budapest.

Hoffman, I. (2013): Önkormányzati közszolgáltatások szervezése és igazgatása - Az elmélet és a gyakorlat tükrében. ELTE Eötvös Kiadó Kft, Budapest.

Horváth, Gy. (2007): Régióközpontok Európában. Magyar Tudomány, 6, 704-720.

Horváth, M. T. (2002): Helyi közszolgáltatások szervezése. Dialóg Campus Kiadó, Budapest.

Jánosa, A. (2011): Adatelemzés SPSS használatával. Computer Books Kiadói Kft, Budapest.

Kiss, É. (2016): Területi különbségek a hazai népesség egészségi állapotában, 1989 után. Területi Statisztika, 56, 5, 483-519. doi:10.15196/TS560501

Kollai, I. (2019): Elszegényítő központi régiók? A területi egyenlőtlenség lehetséges mozgatórugói Szlovákiában. Közgazdasági Szemle, 1125-1144.

Kónya, I. (2015): Több gép vagy nagyobb hatékonyság? Növekedés, tőkeállomány és termelékenység Magyarországon 1995-2013 között. Közgazdasági Szemle, 62, 11, 1117-1139. o.

Kovács, Z. (2016): Városok vonzereje országos és regionális léptékben. In Lengyel, I. - Nagy, B. (szerk.): Térségek versenyképessége, intelligens szakosodása és újraiparosodása. JATEPress, Szeged, 272-289.

Koós, B. (2013): Három évtized a kistelepülések hazai finanszírozásában: A változó fejlődési lehetőségek kora 1980-2005. In Kovács, K. - Váradi, M. M. (szerk.): Hátrányban vidéken. Argumentum Kiadó, Budapest, 275-295.

Koltai, Z. (2016): Városok vonzereje országos és regionális léptékben. In Lengyel I.Nagy B. (szerk.): Térségek versenyképessége, intelligens szakosodása és újraiparosodása. JATEPress, Szeged, 272-289.

Kovács, K. - Somlyódyné, P. E. (szerk) (2008): Függőben. Közszolgáltatás-szervezés a kistelepülések világában. Közigazgatási olvasmányok, KSZK ROP 3.1.1. PROGRAMIGAZGATÓSÁG, Budapest.

Kukely, Gy. (2008): A külföldi müködőtőke beruházások hatása az ipar területi folyamataira Magyarországon, különös tekintettel a delokalizációra. $\mathrm{PhD}$ értekezés, Eötvös Loránd Tudományegyetem,Természettudományi Kar, Földtudományi Doktori Iskola.

Lányi, A. (2008): Esélyek és egyenlőtlenségek a pályázatfinanszírozásban. Educatio, $526-538$.

Lengyel, I. (2016): Competitiveness of metropolitan regions in Visegrad counties. Procedia-Social and Behavioral Sciences, 223, 357-362.

Lengyel, I. - Varga, A. (2019): Földrajz és gazdasági növekedés Magyarországon továbblépés és újabb diagnózisok. Közgazdasági Szemle, 66, 6, 597-606. doi:10.18414/KSZ.2019.6.597

Lentner, C. (2007): A polbári Magyarország új típusú versenyképességi tényezői. Polgári Szemle - Gazdasági és Társadalmi Folyóírat, 3, 2, 30-44.

Lukovics, M. (2008): Térségek versenyképességének mérése. JATEPress, Szeged.

Lux, G. (2012): Fejlesztési problémák és területi együttműködési kapcsolatok magyar. In P. E. Somlyódyné (Szerk.): Az agglomerációk intézményesitésének sajátos kérdése. Publikon Kiadó, Budapest, 153-180. 
Nagy, B. - Fodor, É. (2015): A gazdasági válság hatásai a férfiak és a nők munkaerőpiaci helyzetére Kelet-Közep-Europaban. (Hungarian). Szociológiai Szemle, $25,3,2-22$.

Nemes Nagy, J. (1998): Tér a társadalomkutatásban. Hilscher Rezső Szociálpolitikai Egyesület, Budapest.

Obádovics, Cs. (2018): A népesség szerkezete és jövője. In Monostori, J. - Öri, P. Spéder, Z. (szerk.): Demográfiai portré. KSH Népességtudományi Kutatóintézet, Budapest, 272-294.

Obadovics, Cs. - Bruder, E. (2017): What does young age structure suggest about socio-economic development? Journal of Management, 2, 17-22.

Pusztai, G. (2009): A társadalmi tőke és az iskola. Budapest: ÚMK.

Radó, P. (2007): Oktatási egyenlõtlenségek. Esály, 24-36.

Simonyi, Á. (2000): Versenyképesség jóléti rendszer és közjavak révén. Szociológiai Szemle, 1 .

Siska M. - Szabó, T. (2015): Preferenciák a közlekedési mód megválasztásában Magyarországon. Tér-Gazdaság-Ember, 81-103. Győr

Samu, I. (2019): Csallóköz kistérségeinek egyenlőtlenségei. In Csilla, O. - Emese, B. (Szerk.): Változó társadalom, változó gazdaság, 155-178. Scolar Kiadó, Győr.

Szabó, T. (2019): Public service as an indicator of competitiveness. Területi Statisztika, 213-234. doi:10.15196/RS090211

Szabó, T. (2019): Public service as an indicator of competitiveness . Területi Statisztika, 56, 1, 89-108. doi:10.15196/RS090211

Szabó, T. - Kovács, E. (2018): Közszolgáltatások és térbeli koncentráció. Polgári Szemle, 361-382.

Szerb, L. - Rideg, A. - Kruzslicz, F. - Krabatné Fehér, Z. - Horváth, K. - Hornyák, M. - . . Lukovszki, L. (2019): Kompetencia-alapú versenyképesség-mérés és -elemzés a magyar kisvállalati (mKKV) szektorban. Pécsi Tudományegyetem, Közgazdaságtudományi Kar. Regionális Innovációs- és Vállalkozáskutatási Központ, Pécs.

Szörényiné, K. I. (2005): A fenntartható fejlődés stratégiai elemei a rurális térségekben. Tér és Társadalom, 19, 3-4, 111-137.

Tóth, G. - Bán, A. -Vitrai, J. - Uzzoli, A. (2018): Az egészségügyi ellátáshoz való hozzáférés szerepe az egészségegyenlötlenségekben - A szívizominfarktusmegbetegedések és -halálozások területi különbségei. Területi Statisztika, 346380. doi:10.15196/TS580402

Uzzoli, A. (2015): A gazdasági válság hatásai az egészségi állapotra és az egészségügyi ellátórendszerre: Magyarországi esettanulmány. In Karlovitz, J. T. (szerk.) Fejlődő jogrendszer és gazdasági környezet a változó társadalomban. International Research Institute, Komárno, 303-309. (ISBN:978-80-89691-21-0)

Velkey, G. (2019): A térbeli-társadalmi egyenlőtlenségek és újratermelésük az alapfokú oktatás hazai rendszerében. Tér és Társadalom, 104-131. doi:10.17649/TET.33.4.3191

Zám, É. (2019): A versenyképesség területi statisztikai elemzése. Acta Oeconomica, 34-57. 